\title{
Regional Variations and Determinants of Physical Intimate Partner Violence in Nigeria
}

\author{
Juliana C. Onuh ${ }^{1}$, Chukwuedozie K. Ajaero ${ }^{1 \& 2}$, Emeka E. Igboeli ${ }^{1}$ \\ \& Godslove S. Nnadi ${ }^{1}$ \\ ${ }^{1}$ Department of Geography, Faculty of the Social Sciences, \\ University of Nigeria, Nsukka Nigeria \\ ${ }^{2}$ Demography and Population Studies Programme, Schools of Public Health and \\ Social Sciences, University of the Witwatersrand, \\ Johannesburg, South Africa. \\ E-mail: emeka.igboeli@unn.edu.ng
}

\begin{abstract}
Background: In spite of the need to prevent and mitigate varying occurrences of physical intimate partner violence (IPV) in different regions of the country, regional determinants of physical IPV in Nigeria have remain unexplored. The study, therefore, examines the regional variations of the prevalence and determinants of physical intimate partner violence in Nigeria.

Method: Data was from the 2013 Demographic and Health Survey of Nigeria, which was conducted in all 36 states of Nigeria, and Abuja. A composite index of physical intimate partner violence was used as the outcome variable. Data analysis involved descriptive statistics, mapping, and binary logistic regression.

Results: On National level, $16.25 \%$ of respondents had experienced physical IPV while regional variations in physical IPV was found across the regions with South-South having the highest prevalence (27.10\%). The most significant determinants of physical intimate partner violence at the national level, and across the regions were shown to be: high level of alcohol intake by some husbands, increase in the number of co-wives, increased parity, wealth index, and low levels of women education.

Conclusion: This study recommends sensitization of the public on the negative consequences of excessive alcohol intake, and practice of polygamy, on physical IPV.
\end{abstract}

Keywords: Determinants; Intimate partner violence; Nigeria; Prevalence; Regions

\section{Introduction}

Violence against women is a public health problem throughout the world, with one out of every three women in the world beaten, coerced into sex, or abused during her lifetime. According to the World Health Organization, all behavioral occurrences within an intimate relationship that causes physical, sexual or psychological harm are known as intimate partner violence (IPV) (WHO, 20I6). Over 38\% of women worldwide are killed by their intimate partners and some women, in a bid to escape the chronic cases of IPV, commit suicide or die homeless (WHO, 2016). Physical Intimate partner violence occurs in different manifestations and forms such as kicking, knocking, choking, punching, and confinement (Babu and Kar, 20I0; Alokan, 20I3).

While the lifetime intimate physical or sexual violence among sexual partners is $30 \%$ globally, physical IPV is more prevalent in developing countries (World Health Organization, 20I3). On average,
$36 \%$ of sub-Saharan Africa women subjected to IPV exceeded the global average of $30 \%$, with more women in Africa subjected to lifetime partner violence $(45.6 \%)$ than women anywhere in the world (García-Moreno et al. 2013). Nigeria remains one of the countries in sub-Saharan Africa with high incidence of female domestic abuse (Okemgbo et al. 2002; Odimegwu et al. 2010; Amnesty International, 2012; Udo etal. 2018). A study by Aihie (2009) showed that the most common form of abuse recorded among respondents in Nigeria were shouting at partner (93\%), slapping or pushing (77\%), punching and kicking (40\%). Mbadugha's (2016) study revealed that about $28.2 \%$ to $47.3 \%$ of women experienced physical intimate partner violence. This disturbing data provided the basis for the need to interrogate regional determinants of physical IPV in Nigeria so as to mitigate the occurrence of these acts of partner violence. 
In past years, a growing number of surveys have improved the understanding and knowledge of the scope, consequences, and determinants of IPV in Africa, which is crucial for addressing women's health and development. Studies have continuously shown widespread consequences of IPV, which go beyond physical effects to psychological and social long-term effects. Specifically, physical intimate partner violence has been associated with unintended pregnancy, delayed prenatal care, as well as behavioral risk activities such as smoking, alcohol, and drug abuse (Dureval and Lindsko, 20I5; Mbadugha, 2016). The occurrence of physical IPV among pregnant women also affects both mother and child health by increasing the risk for infant low birth weight, preterm delivery, and neonatal death (Sarkar, 2008). Studies have also reported a positive relationship between IPV and HIV in Africa (Burgos-Soto et al. 20I4; Dureval and Lindsko, 20I5).

Literature has shown that the occurrence of physical IPV cuts across all societal strata, irrespective of age, and it affects both males and females, though more females than males are affected (Obi and Ozumba, 2007; Anolue and Uzoma, 2017). Other factors which have been associated with increased occurrence of physical IPV include unemployment, poverty, and age at first union (Fox \& Benson, 2006; Cunradi et al., 2009; Krishnan et al. 2010; Kwagala et al., 2013; Odimegwu et al. 20/8;), as well as exposure to child maltreatment, witnessing of family violence, poverty, younger ages of women, women with lower educational levels, harmful use of alcohol, antisocial personality disorder, polygamy, infidelity of partners, infertility of women and gender inequality (Ajayi et al. 2018; Mc Coskey et al. 2005; Shah et al., 2013; Owoaje and OlaOlorun, 2012; Modupe et al. 2015; Anolue et al.,2017). A more consistent predictor of physical IPV, even when individual level risk factors are controlled, turns out to be geographical characteristics (Benson et al., 2003; Li et al., 20 I0; Cunradi et al., 20I I; Wright et al., 20I I). It has been established that the occurrence and determinants of physical IPV differ greatly across various spatial areas within, and between countries (Heise and Kotsadam, 2015). For instance, a recent study in Brazil showed that areas associated with higher occurrences of IPV were the municipalities with similar social and economic relationships (Lucena, et al., 20I2; Ribeiro et al., 20I5).

While the determinants of physical intimate partner violence (IPV) have received much attention (Okemgbo et al. 2002; Odimegwu et al. 20I0; Ajayi et al. 20/8), regional variations in the occurrences and the determinants of physical IPV in Nigeria have remained unexplored. It is, therefore, on this basis that this study sets out to examine the regional variations and determinants of physical IPV in Nigeria. This study is very relevant since the understanding of the regional variations and determinants of physical IPV remains indispensable in the identification of regionally vulnerable areas and socioeconomic groups. The identification of these regionally vulnerable areas and the associated socioeconomic factors would assist in setting up public policy, and strategies that would be used to prevent and mitigate the occurrence of physical IPV in different parts of the country. The reduction in physical IPV would subsequently help in achieving the sustainable development goal (SDG-5.2) which seeks to eliminate all forms of violence (including trafficking, sexual and other types of exploitation) against women and girls in public and private spheres.

\section{Methods \\ Study variabes}

This study used data from the 2013 demographic and health survey (DHS) of Nigeria. A total of 38948 women aged 15-49 in 15859 urban and 22663 rural households were interviewed. The survey covered all the six geopolitical regions in Nigeria namely: North Central, North East, North West, South East, South-South, and South West. The study made use of physical intimate partner violence (IPV) as the dependent variable. To generate the composite physical intimate partner violence, responses to the following questions were used: "has the respondent: (i) ever been slapped by husband/partner, (ii) ever been punched with fist or hit by something harmful by husband/partner, (iii) ever been kicked or dragged by husband/partner, (iv) ever been strangled or burnt by husband/partner, ( $v$ ) ever been threatened with knife/gun or other weapon by husband/partner, (vi) ever been threatened with harm by husband/partner, and (vii) ever had the arm twisted or hair pulled by husband/partner. The persons who responded "yes" to one or more of the above questions were classified as having experienced physical intimate partner violence and coded "I", while respondents who answered "never" to all the above questions were classified as having not experienced physical intimate partner violence and coded " 0 ".

The independent variables used in the study were: age, education, place of residence, parity, wealth index, employment status, number of co-wives, husband/partner education, and alcohol intake by husband/partner.

\section{Data analyses}

Before data analysis, the dataset was weighted to account for differences due to under-sampling and over-sampling as per the survey design using the STATA svyset command. Analyses were carried out 
on the basis of the six geopolitical regions earlier identified. Univariate analysis and spatial mapping were used to describe the pattern of physical IPV index, while binary logistic regression model with confidence level of $95 \%$ was used to regionally estimate the factors that influence incidence of physical IPV. All the analyses were carried out using ArcGIS and STATA version I4.0.

\section{Ethical considerations}

This study was a secondary analysis of anonymous data from the Nigeria Demographic and Health Survey (DHS) 20I3. The National Health Research Ethics Committee in Nigeria approved the survey (Approval no: NHREC/0I/0I/2007). Informed consent was obtained from respondents during the process of data collection. Formal approval to use the data was also obtained from the Measure DHS.

\section{Results}

Characteristics of the study population

The characteristics of the respondents varied nationally, and across the different geo-political regions of the study area. On the national level, $60 \%$ and $61.9 \%$ of the respondents resided in rural areas, and were employed respectively. Also, across the regions, over half of the respondents were in rural areas, as opposed to urban areas, with the exception of the South East (with urban population of 33.71\%) and South West (with urban population of $26.38 \%$ ). In addition, a greater proportion of the respondents were aged 20-29 years (Table I). About one-third of the women in all the regions had I-3 children, and more than half of all the women had no co-wives. At least $50 \%$ of the women in all the regions were also employed. 
Table I: Characteristics of the study population

\begin{tabular}{|c|c|c|c|c|c|c|c|}
\hline $\begin{array}{l}\text { Population } \\
\text { Characteristics }\end{array}$ & $\begin{array}{l}\text { Total National } \\
\text { Population }\end{array}$ & North Central & $\begin{array}{l}\text { North } \\
\text { East }\end{array}$ & North West & $\begin{array}{l}\text { South } \\
\text { East }\end{array}$ & South South & South West \\
\hline \multicolumn{8}{|l|}{ Age } \\
\hline $15-19$ & $7840(20.5)$ & $1266(20.34)$ & I299(19.78) & 1923(19.95) & $883(19.88)$ & |374(22.82) & $1134(19.38)$ \\
\hline $20-29$ & $13506(35.3)$ & $24 \mid 7(38.83)$ & $2432(37.03)$ & $3408(35.36)$ & $|5| \mid(34.02)$ & $2073(34.42)$ & $1845(31.53)$ \\
\hline $30-39$ & $9874(25.8)$ & $1535(24.66)$ & $1688(25.70)$ & $2483(25.77)$ & $1080(24.32)$ & $1528(25.37)$ & $1700(29.05)$ \\
\hline $40-49$ & $7080(18.5)$ & $1007(16.18)$ & II48(I7.48) & $1823(18.92)$ & $967(21.77)$ & $1047(17.39)$ & $1173(20.04)$ \\
\hline \multicolumn{8}{|l|}{ Education } \\
\hline None & $13440(35.1)$ & $1618(25.99)$ & $392 I(59.7 I)$ & 7030(72.95) & $253(5.70)$ & $334(5.55)$ & $493(8.42)$ \\
\hline Primary & $6990(18.3)$ & $1387(22.28)$ & $1034(15.75)$ & $1072(11.12)$ & $95 I(2 I .4 I)$ & $1542(25.61)$ & $1087(\mid 8.57)$ \\
\hline Secondary & I4220(37.I) & $2413(38.76)$ & $1279(19.48)$ & $1330(13.80)$ & $2626(59.13)$ & $3459(57.44)$ & $3234(55.26)$ \\
\hline Tertiary & $3650(9.5)$ & $807(12.96)$ & $333(5.07)$ & $205(2.13)$ & $611(13.76)$ & $687(\mid 1.4 I)$ & $1038(17.74)$ \\
\hline \multicolumn{8}{|l|}{ Residence } \\
\hline Urban & $15325(40.0)$ & $220 \mathrm{I}(35.36)$ & $1589(24.20)$ & $2380(24.70)$ & $2944(66.29)$ & $205 I(34.06)$ & $4308(73.62)$ \\
\hline Rural & $22975(60.0)$ & $4024(64.64)$ & $4978(75.80)$ & $7257(75.30)$ & I497(33.7I) & $397 \mid(65.94)$ & I544(26.38) \\
\hline \multicolumn{8}{|l|}{ Parity } \\
\hline None & II430(29.9) & 2055(33.0I) & I529(23.28) & $1937(20.10)$ & I836(4I.34) & $2224(36.93)$ & $1890(32.30)$ \\
\hline I-3 children & $11970(31.3)$ & $2042(32.80)$ & $206 \mid(3 \mid .38)$ & 2897(30.06) & $1155(26.01)$ & $1904(31.62)$ & $2116(36.16)$ \\
\hline 4-6 children & $9211(24.1)$ & $1599(25.69)$ & $1610(24.52)$ & $2462(25.55)$ & $887(19.97)$ & $1297(21.54)$ & $1488(25.43)$ \\
\hline $7+$ children & $5689(14.9)$ & $529(8.50)$ & $1367(20.82)$ & $234 I(24.29)$ & $563(\mid 2.68)$ & $597(9.91)$ & $358(6.12)$ \\
\hline \multicolumn{8}{|l|}{ Wealth } \\
\hline Poorest & $6469(16.9)$ & $443(7.12)$ & $2319(35.31)$ & $3480(36.11)$ & $20 I(4.53)$ & $3 I(0.5 I)$ & $81(1.38)$ \\
\hline Poorer & $7360(19.2)$ & IIII(I7.85) & $1890(28.78)$ & $2910(30.20)$ & $589(\mid 3.26)$ & $584(9.70)$ & $379(6.48)$ \\
\hline Middle & 7876(20.6) & $|87|(30.06)$ & $1097(16.70)$ & |483(I5.39) & $1153(25.96)$ & I586(26.34) & $779(|3.3|)$ \\
\hline Richer & $8337(21.8)$ & I374(22.07) & $736(11.21)$ & $1091(11.32)$ & $1353(30.47)$ & $2049(34.03)$ & $1810(30.93)$ \\
\hline Richest & $8258(21.6)$ & |426(22.9|) & $525(7.99)$ & $673(6.98)$ & $1145(25.78)$ & I772(29.43) & $2803(47.90)$ \\
\hline \multicolumn{8}{|l|}{ No of other wives } \\
\hline None & $17860(66.9)$ & $2931(70.6 I)$ & $3015(57.62)$ & $4558(55.22)$ & $2030(88.38)$ & $267 \mid(82.3 I)$ & $2793(74.68)$ \\
\hline $\begin{array}{l}\text { I } \\
\text { http://aps.journals.ac.za }\end{array}$ & $6925(26.0)$ & $985(23.73)$ & $1672(31.95)$ & $3017(36.55)$ & $8^{204(8.88)}$ & $417(12.85)$ & $705(\mid 8.85)$ \\
\hline
\end{tabular}


African Population Studies Vol 32, No 2, (Supp. 2), Sept. 2018

\begin{tabular}{|c|c|c|c|c|c|c|c|}
\hline 2 & $1472(5.5)$ & $174(4.19)$ & $434(8.29)$ & $566(6.86)$ & $38(1.65)$ & $109(3.36)$ & I64(4.39) \\
\hline $3+$ & $434(1.6)$ & $6 \mathrm{I}(1.47$ & $112(2.14)$ & $113(1.37)$ & $25(1.09)$ & $48(I .48)$ & $78(2.09)$ \\
\hline \multicolumn{8}{|l|}{ Employed } \\
\hline No & $145 \mid 8(38.1)$ & $2103(33.98)$ & $3203(49.05)$ & $4062(42.42)$ & $1570(35.58)$ & $2122(35.42)$ & $1608(27.57)$ \\
\hline Yes & $23584(61.9)$ & $4086(66.02)$ & $3327(50.95)$ & $55 \mid 9(57.60)$ & $2842(64.42)$ & $3869(64.58)$ & $4225(72.43)$ \\
\hline \multicolumn{8}{|c|}{ Husband drinks } \\
\hline No & I7258(79.2) & $2834(80.83)$ & $356 \mid(90.22$ & $6025(97.59)$ & 1034(49.33) & |393(46.7|) & $2654(77.69)$ \\
\hline Yes & $4534(20.8)$ & $672(19.17)$ & $386(9.78)$ & $149(2.4 \mid)$ & $1062(50.67)$ & 1589(53.29) & $762(22.31)$ \\
\hline \multicolumn{8}{|c|}{ Partner Education } \\
\hline None & 10576(37.1) & $995(22.7 \mathrm{I})$ & $3167(57.89)$ & $5546(65.73)$ & $256(9.86)$ & 204(5.64) & $408(10.23)$ \\
\hline Primary & $5534(19.4)$ & $831(18.97)$ & $729(13.63)$ & $1150(13.63)$ & $1065(41.01)$ & $944(26.12)$ & $815(20.43)$ \\
\hline Secondary & $8161(28.6)$ & 1472(33.60) & $946(\mid 7.29)$ & $1 \mid 23(|3.3|)$ & $984(37.89)$ & $1822(50.42)$ & $18 \mid 4(45.46)$ \\
\hline Tertiary & $4220(14.8)$ & $1083(24.72)$ & $629(11.50)$ & $619(7.34)$ & $292(11.24)$ & $644(17.82)$ & $953(23.88)$ \\
\hline
\end{tabular}


Prevalence of physical intimate partner violence On a national level, $16.25 \%$ of the respondents had experienced physical IPV while across the regions, the proportion of women who reported physical IPV ranged from $4.5 \%$ in North West to $27.1 \%$ in South South (Figure I).

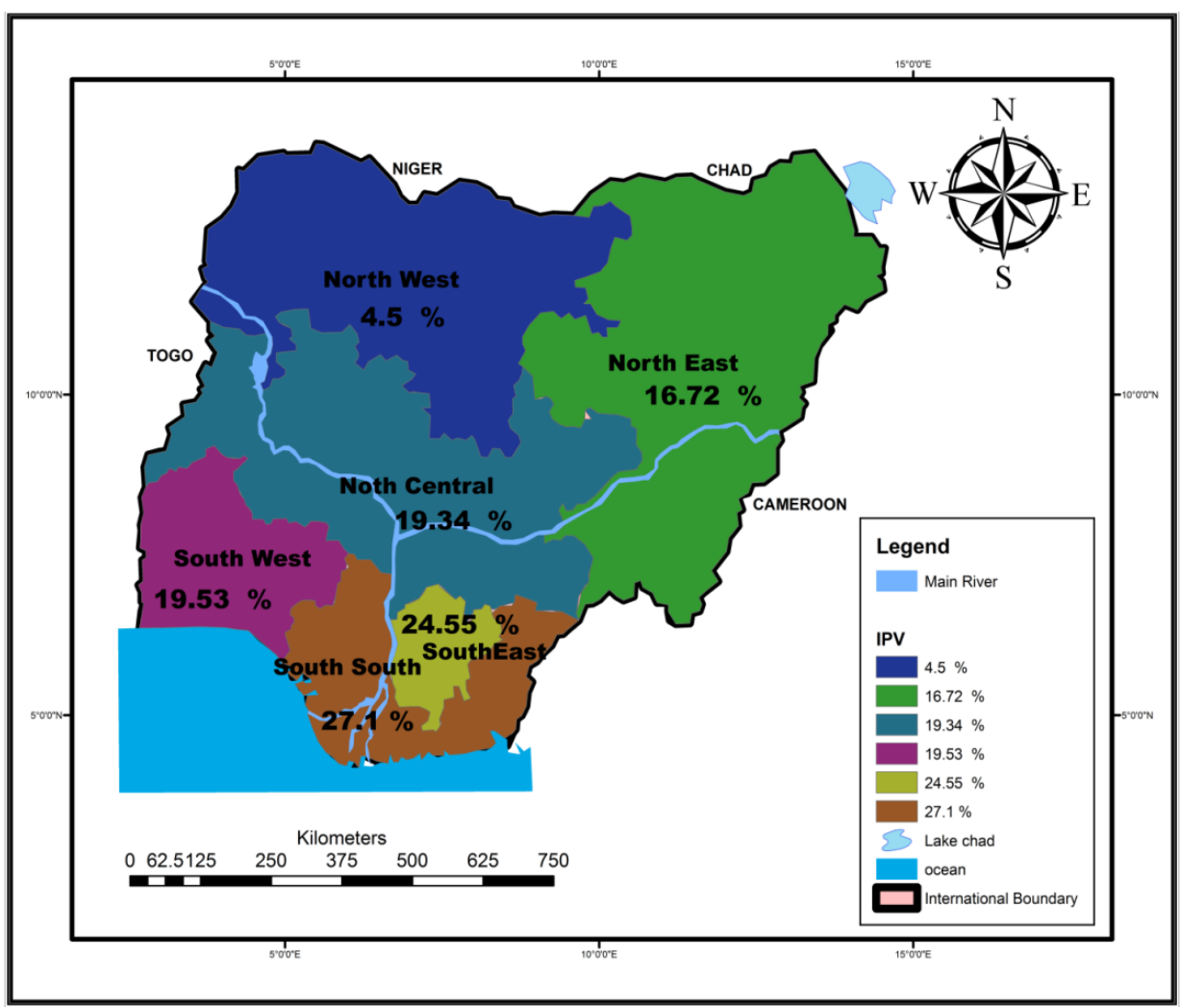

Figure I: Regional prevalence of physical intimate partner violence in Nigeria

Variations in the occurrence of physical IPV also existed across the states within each of the regions (Figure 2). For instance, the South East region has relatively high prevalence of physical IPV but within the region, Abia State has very low prevalence while Ebonyi State has very high prevalence of physical IPV.

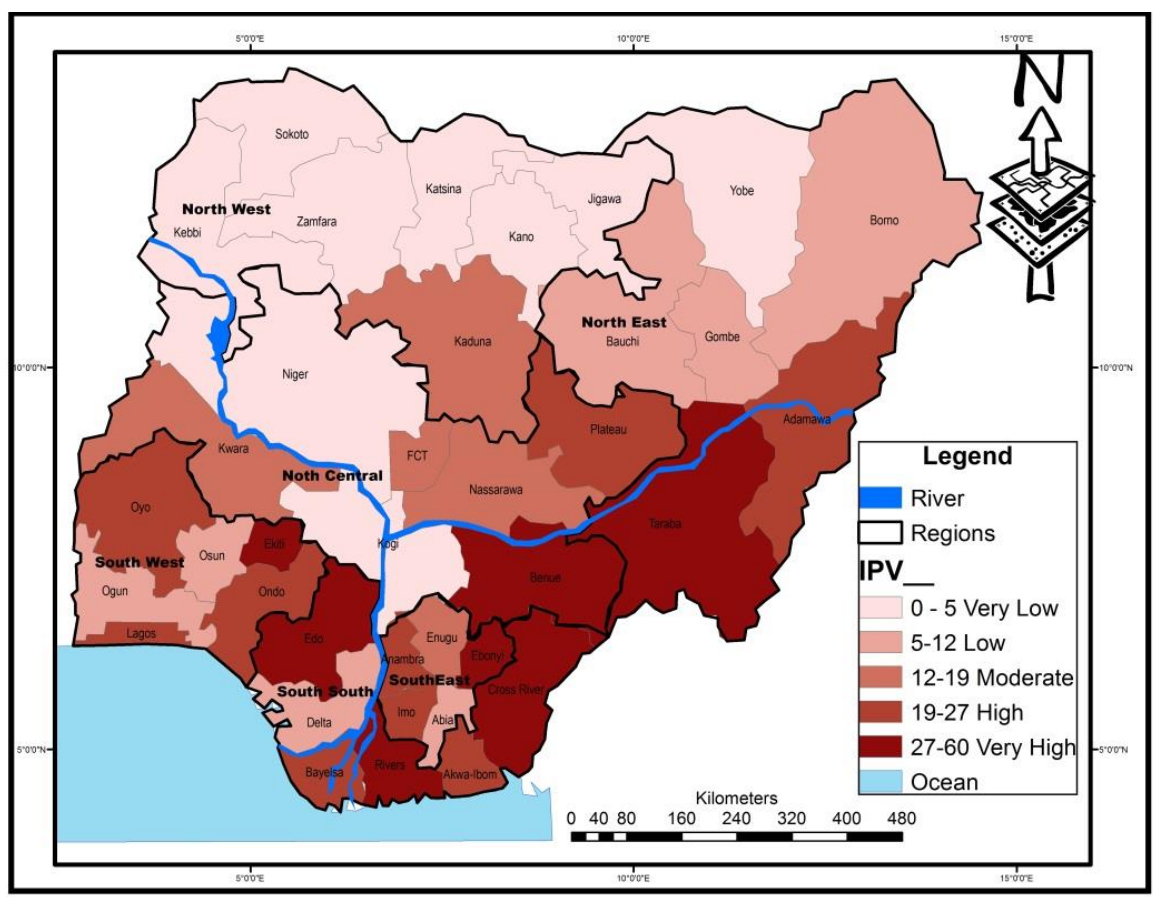

Figure 2: Variations in the prevalence of pysical intimate partner violence within the Regions 
Determinants of physical intimate partner The regression analysis results show variations violence between the national and regional determinants of physical IPV in the study area (Tables 2 ).

Table 2: Binary logistic regression results of regional determinants of physical intimate partner violence in Nigeria

\begin{tabular}{|c|c|c|c|c|c|c|c|}
\hline Variables & $\begin{array}{l}\text { Total } \\
\text { National } \\
\text { Population }\end{array}$ & $\begin{array}{l}\text { North } \\
\text { Central }\end{array}$ & $\begin{array}{l}\text { North } \\
\text { East }\end{array}$ & $\begin{array}{l}\text { North } \\
\text { West }\end{array}$ & $\begin{array}{l}\text { South } \\
\text { East }\end{array}$ & $\begin{array}{l}\text { South } \\
\text { South }\end{array}$ & $\begin{array}{l}\text { South } \\
\text { West }\end{array}$ \\
\hline \multicolumn{8}{|l|}{ Age: I5-19 (RC) } \\
\hline $20-29$ & $1.32 * *$ & 1.25 & 1.34 & 1.02 & 1.71 & 1.05 & 0.99 \\
\hline $30-39$ & $1.42 * * *$ & 1.12 & 1.51 & 1.07 & 1.96 & 0.92 & 1.11 \\
\hline $40-49$ & 1.25 & 0.93 & $1.82 *$ & 0.89 & 1.65 & 0.67 & 0.766 \\
\hline \multicolumn{8}{|l|}{ Education: None (RC) } \\
\hline Primary & $1.85^{* * * *}$ & I.75**** & 1.14 & $0.7 \mathrm{I}$ & 1.08 & $1.90 * *$ & $1.59 *$ \\
\hline Secondary & $1.67 * * *$ & $1.82^{* * * *}$ & 1.19 & 1.35 & 0.98 & $2.04 * *$ & 1.34 \\
\hline Tertiary & $1.40 * * *$ & 0.93 & 0.91 & 0.66 & 0.52 & 1.35 & 0.65 \\
\hline \multicolumn{8}{|l|}{ Residence: Urban (RC) } \\
\hline Rural & $0.89 *$ & 0.80 & $1.6 I^{* * *}$ & 0.91 & $0.72 *$ & $0.74 * *$ & $0.75^{*}$ \\
\hline \multicolumn{8}{|l|}{ Parity: None (RC) } \\
\hline I-3 children & $1.62 * * * *$ & $2.26 * *$ & 1.30 & 1.39 & 1.68 & 1.46 & $2.08^{*}$ \\
\hline 4-6 children & $1.76 * * *$ & 2.70 **** & $1.56 *$ & 1.14 & $1.92 *$ & 1.38 & $2.69 * *$ \\
\hline $7+$ children & $1.70 * * *$ & $3.54 * * * *$ & 1.36 & 1.18 & 1.55 & $1.93 * *$ & $2.67^{*}$ \\
\hline \multicolumn{8}{|l|}{ Wealth: Poorest(RC) } \\
\hline Poorer & 1.06 & 1.24 & 0.86 & 0.9 & 1.81 & 1.56 & $3.40 *$ \\
\hline Middle & 0.89 & 0.88 & 0.78 & $0.53^{*}$ & 1.65 & 2.00 & $\mathrm{I} .74$ \\
\hline Richer & $0.73^{* * *}$ & $0.58^{*}$ & 0.74 & 0.98 & 1.36 & 1.55 & 1.46 \\
\hline $\begin{array}{l}\text { Richest } \\
\text { No of other wives: } \\
\text { O(RC) }\end{array}$ & $0.64 * * *$ & $0.5 I^{*}$ & 1.17 & 1.13 & 0.84 & 1.03 & 1.59 \\
\hline 1 & $1.20 * * *$ & 1.23 & 1.25 & 1.08 & $\mathrm{I} .83 * *$ & $1.4 I^{*}$ & 1.08 \\
\hline 2 & $1.32 *$ & $2.04 *$ & 1.16 & 0.95 & 0.86 & $1.65^{*}$ & 1.04 \\
\hline $3+$ & $2.00 * * *$ & $3.52 * *$ & 0.31 & $4.38 * *$ & 2.01 & 1.16 & $2.4 I^{*} *$ \\
\hline \multicolumn{8}{|l|}{ Working: No(RC) } \\
\hline $\begin{array}{l}\text { Yes } \\
\text { Partner drinks: } \\
\text { No(RC) }\end{array}$ & 1.09 & 1.14 & I. $45 * * *$ & 0.98 & 0.91 & $0.7 I^{* *}$ & 0.98 \\
\hline $\begin{array}{l}\text { Yes } \\
\text { Partner Education: } \\
\text { None(RC) }\end{array}$ & $3.66 * * *$ & $3.99 * * *$ & $6.24 * * *$ & $26.8^{* * * *}$ & $2.20 * * *$ & I.58**** & 2.27 **** \\
\hline Primary & $1.74 * * *$ & $1.47^{*}$ & $1.94 * * *$ & 1.52 & 1.02 & 1.19 & 1.08 \\
\hline Secondary & $1.67 * * * *$ & $1.60 * *$ & I.72** & 1.47 & 0.88 & 0.96 & 0.89 \\
\hline $\begin{array}{l}\text { Tertiary } \\
\quad * p<0.05 ; * * * 0.0\end{array}$ & $\begin{array}{l}\text { I. } .4 \mathrm{I}^{* * * *} \\
* * * p<0.00 \mathrm{I}\end{array}$ & I.46* & $1.55^{*}$ & 0.69 & 1.23 & 0.68 & 0.76 \\
\hline
\end{tabular}

While the variable of partner who drinks alchohol showed increased and significant odds of physical IPV at the national level, and in all the regions, parity and number of co-wives show increased and significant odds of physical IPV at the national level, and in only five regions. Also, usual residence shows significant odds of physical IPV at the national level, and in five regions, while age shows increased and significant 
odds of physical IPV at the national level, and in only the North East region. A partner with high intake of alcohol increased the odds of physical IPV at the national level $(O R=3.66 ; p<0.000)$, in North-Central $(\mathrm{OR}=3.995 ; \mathrm{p}<0.000)$, North-East $(\mathrm{OR}=6.239$; $p=0.000)$, North-West $(O R=26.79 ; p=0.000)$, South-East $(O R=2.203 ; p<0.000)$, South-South $(O R=1.582 ; p<0.000)$, and South-West $(O R=$ 2.269; $p<0.000)$. On the other hand, rural residency shows significant and increased odds of physical IPV in North East (OR $=1.6 \mathrm{I} 3 ; \mathrm{p}=0.00 \mathrm{I})$, but decreased odds of physical IPV at the national level $(O R=0.89$; $p<0.05)$, in South East $(O R=0.724 ; p<0.05)$, South South $(O R=0.742 ; p<0.00 I)$, and South West $(O R=0.750 ; p<0.05)$.

\section{Discussion}

The study provided empirical results from a nationally representative dataset on the national and regional variations in the prevalence of physical IPV in Nigeria, as distinct from community based survey data (Aihie, 2009; Akinsanya-Alo, Odusina \& Gbadebo, 2012; Anolue \& Uzoma, 2017). Another finding of the study is the revelation that the national prevalence $(16.25 \%)$ and highest regional prevalence of physical IPV (27.I\%) are far much below the global average of $30 \%$ and that of sub-Saharan Africa average of $36 \%$ (Garcia-Moreno et al, 20l3). The study also agrees with the findings of Wright et al (20I I), Lori and Kotsadam (20I5), and Ribeiro et al (20I5), which posit that the prevalence and determinants of IPV vary regionally within countries and between countries.

The results at the national level, and across regions generally show that younger women are more susceptible to physical IPV. This finding agrees with earlier studies by Okemgbo et al, (2002), McCloskey et al. (2005) and Shah et al. (2013) that younger women suffer more of IPV than their older counterparts. In addition, the study found that urban residency increased the odds of physical IPV at both the national level, and across the regions. This finding supports earlier studies by Okemgo et al, (2002; 2014) which note that place of residence significantly influence the occurrence of imtimate partner violence.

Education was a significant factor at the national level, and in three (North Central, South South, and South West) out of the six regions with regard to physical IPV, whereby women with lower levels of education suffered more from physical IPV. The findings support the view of Shah et al. (20I3), which noted that lower educational levels increased the possibilities of women experiencing IPV. Parity exerted significant influence at the national level, and in five out of the six regions with regard to incidence of physical IPV. There was a significant tendency for a partner who drinks, according to the findings of this study, to be involved in physical IPV at the national level, and in five out of the six regions of the country. These results, therefore, support the views of Kwagala et al (2013) and Dureval and Lindsko (20I5) that women who live with partners that drink alcohol are more susceptible to physical IPV.

\section{Conclusion and recommendations}

This study has shown that there are significant national and regional differences regarding the prevalence and determinants of physical IPV in the country. The major determinants of physical IPV were shown to be: male partners who have high intake of alcohol, lower educational levels of women, increase in parity, household wealth index, number of co-wives, and urban residence of the women. The study, therefore, recommends the application of regionally varying policies targeted at the regionally varying determinants of physical IPV in the country. One of the region-specific intervention measures/strategies that will help reduce incidence of physical IPV is the sensitization of men on the negative consequences of excessive alcohol intake and practice of polygamy. In addition, there should be increased media awareness and provision of counseling services on the consequences and management strategies of physical IPV,especially in urban areas.

\section{References}

Abramsky, T, Watts, C.H., Garcia-Moreno, C., Devries, K., Kiss, L., Ellsberg, M., Jansen, A.F.M., Heise, L. (20I6). What factors are associated with recent intimate partner violence?: Findings from the WHO Multi-country Study on Women's Health and Domestic Violence". http://www.who.int/ reproductivehealth/topics/violence/mcstudy/en/in dex.html.

AfrolNews. (2007). Half of Nigeria's Women experience domestic violence http://www.afro.com/awrticles/ /647 I

Aihie O.N. (2009). Prevalence of Domestic Violence in Nigeria: Implications for Counseling. Edo Journal of Counseling, 2 (I): I-8

Ajayi, L.A., \& Soyinka-Airewele, P. (20/8). Key Triggers of domestic violence in Ghana: A victim centered analysis. African Population Studies. 32. (I):4097-4I 08

Akinsanya-Alo, O., Odusina, E.K., Gbadebo, B. (2012). Spousal Violence in South West Nigeria: Prevalence and Correlates. Journal of Women's Health Care; I (2): I-8 
Ali, T. S., Mogren, I., \& Krantz, G. (20I3). Intimate Partner Violence and Mental Health Effects: A Population-based Study among Married Women in Karachi, Pakistan. International Journal of Behavioral Medicine, 20, I31-139.

Alokan, F.B. (20/3). Domestic Violence against Women; a Family Menace, Paper presented at the Ist Annual International Interdisciplinary Conference (AllC): 24-26

Amnesty International. (20/2). The State of the World's Human Rights. Geneva, Switzerland. Retrieved from http://www.amnestyusa.org/sites/default/files/air I 2-report-english.pdf

Anolue, F. C., Uzoma, O. I. (20I7). Intimate Partner Violence: Prevalence, Contributing Factors and Spectrum among Married Couples in Southeast Nigeria, International Journal of Reproductive Contraception obstetrics and gynecology; 6(9):3748-3753 DOI: http://dx.doi.org/10.18203/2320I770.ijrcog20174019

Babu, B.V., Kar, S.K. (20I0). Domestic Violence in Eastern India: Factors associated with Victimization and Perpetration. Public health Journal; | 24: | 36- | 48.

Benson, M.L.; Fox, G.L.; DeMaris, A.; Van Wyk, J. (2003). Neighborhood Disadvantage, Individual Economic Distress and Violence against Women in Intimate Relationships. J. Quant. Criminol. 19, 207-235.

Burgos-Soto, J., Orne-Gliemann, J., Encrenaz, G., Patassi, A., Woronowski, A., Kariyiare, B., Becquet, R. (20|4). Intimate Partner Sexual and Physical Violence among Women in Togo, West Africa: Prevalence, Associated Factors, and the Specific Role of HIV Infection. Global Health Action, 7, 23456. http://dx.doi.org//0.3402/gha.v7 .23456

Chibber, K.S., Krupp, K., Padian, N., Madhivanan, P. (2012). Examining the Determinants of Sexual Violence among Young, Married Women in Southern India. J Interpers Violence; 27:24652483.

Cunradi, C. B., Todd, M., Duke, M., \& Ames, G. 2009. Problem Drinking, Unemployment, and Intimate Partner Violence among a Sample of Construction Industry Workers and their Partners. Journal of Family Violence; 24, 63-74. http://dx.doi.org// 0. 1007/ s 10896-008-9209-0

Cunradi, C.B.; Mair, C.; Ponicki, W.; Remer, L. (20II). Alcohol Outlets, Neighborhood Characteristics, and Intimate Partner Violence: Ecological Analysis of a California city. J. Urban Health, 88, |9|-200.
Dalal, K., Lindqvist, K. (20/2). A National Study of the Prevalence and Correlates of Domestic Violence among Women in India. Asia Pac J Public Health, 24:265-277.

Durevall, D. \& Lindskog, A. (20I5). Intimate Partner Violence and HIV in ten sub- Saharan African countries: What do the demographic and health surveys tell us? Lancet: Global Health; 3, e34-e43. http://dx.doi.org/I0.1016/S22 |4-I09X(I4)703432

Ellsberg, M., Jansen, H. A., Heise, L., Watts, C. H., \& Garcia- Moreno, C. (2008). Intimate Partner Violence and Women's Physical and Mental Health in the WHO Multi-country Study on Women's Health and Domestic Violence: An Observational Study. The Lancet, 37I, II65-II72.

Ezegwui, H.U., Ikeme, A.C., Onwasigwe, C.N. (2003). Domestic Violence against Pregnant Nigerian Women. Tropical Journal of obstetrics Gynaecol; 20(2): I I6-8.

Fontes K.B., Jacinto Alarcao, A.C, Nihei, O.K., Pelloso, S.M., Andrade, L., and Carvalho, M.D. (20/8). Regional Disparities in the Intimate Partner Sexual Violence Rate against Women in Parana State, Brazil, 2009-2014: An Ecological Study. BMJ Open 20I8; 8:e018437. doi:|0.I|36/ bmjopen-20I7-0I8437

Fox, G. L., \& Benson, M. L. (2006). Household and Neighborhood Contexts of Intimate Partner Violence. Public Health Reports; I I I, 4I 9-427.

Garcia-Moreno C., Jansen H.A., Ellsberg, M., Heise, L., Watts, C.H. (2006). Prevalence of Intimate Partner Violence: Findings from the WHO Multicountry Study on Women's Health and Domestic Violence.

García-Moreno, C., Pallitto, C., Devries, K., Stöckl, H., Watts, C. \& Abrahams, N. (2013). Global and Regional Estimates of Violence against Women. Geneva, Switzerland. World Health Organization. http://apps.who.int/iris/bitstream/I 0665/85239/I/ 978924I564625_eng.pdf

Heise, L.L \& Kotsadam, K. (2015). Cross-national and Multilevel Correlates of Partner Violence: An Analysis of Data from Population-based Surveys. Lancet Glob Health 20I5;3: e332-40

Kimuna, S.R., Djamba, Y.K., Ciciurkaite, G., Cherukuri, S. (20I3).Domestic Violence in India: Insights from the 2005-2006 National Family Health Survey. Journal of Interpers Violence; 28:773-807.

Krishnan, S., Rocca, C. H., Hubbard, A. E., Subbiah, K., Edmeades, J. \& Padian, N. S. (20I0). Do changes in spousal employment status lead to domestic violence?: Insights from a prospective study in Bangalore, India. Social Science \& Medicine; 70, 136-143. 
Kwagala, B., Wandera, S. O., Ndugga, P., \& Kabagenyi, A. (20/3). Empowerment, Partner's Behaviours and Intimate Partner Physical Violence among Married Women in Uganda. BMC Public Health, I3, III2. http://dx.doi.org/I0.I I86/I47I2458-I 3-I I I 2

Larsen, M.M. (2016). Health Inequities Related to Intimate Partner Violence Against Women, Social Disparities in Health and Health Care", Springer International Publishing Switzerland. DOI 10.1007/978-3-319-29565-7_2

Li, Q.; Kirby, R.S.; Sigler, R.T.; Hwang, S.; LaGory, M.E.; Goldenberg, R.L. (20I0). A Multilevel Analysis of Individual, Household, and Neighborhood Correlates of Intimate Partner Violence among Low-income Pregnant Women in Jefferson County, Alabama. Am. J. Public Health, 100, 53I-539.

Lucena, K.D., Silva, A.T, Moraes, R.M., et al. (20I2). Spatial Analysis of Domestic Violence against Women from 2002 to 2005 in João Pessoa, Paraíba State, Brazil. Cad Saude Publica 28: I I I I21.

Mbadugha, E.I. (2016). Intimate partner violence and sexual violence against women: Any end in sight? International Journal of Medicine and Biomedical Research Vol. 5

McCloskey, L. A., Williams, C., \& Larsen, U. (2005). Gender Inequality and Intimate Partner Violence among Women in Moshi, Tanzania. International Family Planning Perspectives; 3I (3), I24-I30.

Modupe O. Onigbogi, Kofoworola A. Odeyemi and Olanrewaju O. Onigbogi, (20I5). Prevalence and Factors Associated with Intimate Partner Violence among Married Women in an Urban Community in Lagos State, Nigeria. African Journal of Reproductive Health. I9 (I): 91

Obi, S. N. and Ozumba B.C. (2007). Factors Associated with Domestic Violence in South-East Nigeria. Journal of Obstetrics and Gynecology. 27. (I) $75-78$

Odimegwu, C., Frade, S. (20/8). The influence of adolescent age at first union on physical intimate partner violence and fertility in Uganda: A path analysis. South Africa Journal of Child Health.12(2): 5I-56

Okemgbo, C.N., Omideyi, A.K., Odimegwu, C.O. (2002). Prevalence, Patterns and Correlates of Domestic Violence in Selected Igbo Communities of Imo State, Nigeria. African Journal of Reproductive Health; Vol. 6(2): I0I-I I 4.

Okemgbo, C.N., Omideyi, A.K. and Odimegwu, C.O. (20I4). Prevalence, Patterns and Correlates of Domestic Violence in Selected Igbo Communities of Imo State, Nigeria.Women's
Health and Action Research Centre (WHARC) collaborating with JSTOR

Okenwa, L., Lawoko, S., \& Jansson, B. (20II). Contraception, Reproductive Health and Pregnancy Outcomes among Women Exposed to Intimate Partner Violence in Nigeria. The European Journal of Contraception \& Reproductive Health Care, 16(I), I8-25.

Owoaje, E.T., OlaOlorun, F. (20I2). Women at Risk of Physical Intimate Partner Violence: A Crosssectional Analysis of a Low-income Community in Southwest, Nigeria. African Journal of Reproductive Health; Vol I6(I):43- 53.

Ribeiro, M.I.C., Silva, M. and das, G.S.N. (20I5). Violence, Vulnerability and Social and Spatial Inequality: An Analysis of the Difficulties faced by Women who are Victims of Domestic Violence in the Urban Area of Porto Velho - RO. Revista Latino-americana de Geografia e Gênero 2015;6:92-104

Sarkar N.N. (2008). The Impact of Intimate Partner Violence on Women's Reproductive Health and Pregnancy Outcome. Journal of obstetrics Gynaecol; Vol. 28:266-7I

Shah, M., Muyingo, M., Byamugisha, J., Aderu, D., Kudesia, R. \& Klatsky, P. (20|3). Infertility and Gender-based Violence in Kampala, Uganda, Fertility and Sterility; 3, SI 43.

Shamu, S., Abrahams, N., Temmerman, M., Musekiwa, A. \& Zarowsky, A. (20II). A Systematic Review of African Studies on Intimate Partner Violence against Pregnant Women: Prevalence and Risk Factors. PLoS One; 6(3): 1759I. Sheridan, D. J., \& Nash, K. R. (2007). Acute Injury Patterns of Intimate Partner Violence Victims. Trauma, Violence, \& Abuse, 8,28I-289.

Steinberg, L., Catalano, R. \& Dooley, D. (I98I). Economic Antecedents of Child Abuse and Neglect. Child Development; 52, 975-985.

Udo, I.E., Doctor, H.V. and Ahonsi, B.A. (2018). Intimate partner violence and uptake of HIV testing and STI treatment among married women in Nigeria. African Population Studies, 32 (I).

Umeora, O.U., Dimejesi, B.I., Ejikeme, B.N., Egwuatu, V.E. (2008).Pattern and Determinants of Domestic Violence among Prenatal Clinic Attendees in a Referral Centre, South-east Nigeria. Journal of obstetrics Gynaecol: 28(8):769-74.

Uthman, O. A., Lawoko, S., \& Moradi, T. (2009). Factors Associated with Attitudes Towards Intimate Partner Violence against Women: A Comparative Analysis of 17 Sub-Saharan Countries.BMC International Health and Human Rights, 9(I), Article I4 
World Health Organization, WHO. (20I0). Preventing Intimate Partner and Sexual Violence Against Women: Taking Action and Generating Evidence. World Health Organization, Geneva, Switzerland.

World Health Organization (20/3). Global and Regional Estimates of Violence against Women Prevalence and Health Effects of Intimate Partner Violence and Non-partner Sexual Violence. In Global and Regional Estimates of Violence against Women Prevalence and Health Effects of Intimate Partner Violence and Non-partner Sexual
Violence. World Health Organization, Geneva. P57

World Health Organization. (2016). Global Plan of Action: Health systems address violence against women and girls World Health Assembly, Resolution 69.

Wright, E.M.; Benson, M.L. (20l I). Clarifying the Effects of Neighborhood Disadvantage and Collective Efficacy on Violence "behind closed doors". Justice Q, 28, 775-798 